\title{
Short Communication: Bivariate Genetic Analysis of Clinical Mastitis and Somatic Cell Count in Norwegian Dairy Cattle
}

\author{
J. Ødegård, B. Heringstad, and G. Klemetsdal \\ Department of Animal and Aquacultural Sciences, \\ Agricultural University of Norway, P.O. Box 5003, N-1432 Ås, Norway
}

\begin{abstract}
Clinical mastitis (CM) and lactation mean somatic cell score (LSCS) were analyzed with a bivariate linear sire model. Nearly 1.4 million primiparous cows of Norwegian Dairy Cattle from 2043 sires were used. The heritability estimates were 0.03 for $\mathrm{CM}$ and 0.11 for LSCS. The estimates of genetic and residual correlations between the 2 traits were 0.53 and 0.10 , respectively. It is postulated that the genetic correlation probably is highly population-specific.

(Key words: dairy cattle, genetic correlation, clinical mastitis, somatic cell count)
\end{abstract}

Abbreviation key: $\mathbf{C M}=$ clinical mastitis, LSCS = lactation mean somatic cell score, $\mathbf{N R F}=$ Norwegian Dairy Cattle.

In recent years, selection for improved resistance to mastitis has become increasingly important in dairy cattle breeding programs. However, routine recording of mastitis is not common outside the Nordic countries. Genetic evaluation of mastitis is therefore mainly based on correlated traits, particularly SCC. The genetic correlation between clinical mastitis $(\mathbf{C M})$ and SCC has been estimated in several studies; Mrode and Swanson (1996) concluded that the average genetic correlation based on values from the literature was approximately 0.7. Most studies have been based on small data sets. The aim of this study was to estimate the genetic correlation between $\mathrm{CM}$ and lactation mean somatic cell score (LSCS) in the Norwegian Dairy Cattle (NRF) population using the largest data set so far analyzed.

Data were from first-lactation daughters of $2043 \mathrm{NRF}$ sires tested from 1978 through 1995 . The data set included records of $1,372,413$ cows with first calvings in the period from 1978 to 1995 . Somatic cell counts were recorded bimonthly and were restricted to those with values between 5000 and $6,400,000$ cells $/ \mathrm{mL}$, in the

Received February 18, 2004

Accepted June 7, 2004.

Corresponding author: Jørgen Ødegård; e-mail: jorgen.odegard@ iha.nlh.no. period 6 to 305 DIM. Furthermore, SCS was defined as $\ln \left((\mathrm{SCC} / \mathrm{mL})^{*} 10^{-3}\right)$, and averaged per cow to LSCS. The trait CM was defined as a binary trait based on whether or not the cow had at least one recorded veterinary treatment of $\mathrm{CM}$ in the period from $15 \mathrm{~d}$ before to 305 $\mathrm{d}$ after first calving (CM equal to 1 or 0 , respectively). For both traits, records were included if age at first calving was in the interval from 15 to $40 \mathrm{mo}$, and lactation started with normal calving. Summary statistics of the data set used in the analysis are presented in Table 1. Sire pedigree was traced back as far as possible through sires and maternal grandsires. A total of 2355 males, including 2043 sires with daughters in the data set, were represented in the pedigree file.

A bivariate analysis was carried out using the following linear sire model for both traits:

$$
\mathrm{Y}_{\mathrm{ijklm}}=\mathrm{A}_{\mathrm{i}}+\mathrm{M}_{\mathrm{j}}+\mathrm{HY}_{\mathrm{k}}+\mathrm{s}_{\mathrm{l}}+\mathrm{e}_{\mathrm{ijklm}},
$$

where $\mathrm{Y}_{\mathrm{ijklm}}=$ observation of CM or LSCS for daughter $m$ of sire $l$, calving at age $i$, in month $j$, and herd-year class $k, \mathrm{~A}_{\mathrm{i}}=$ fixed effect of age $i$ at first calving, in 15 classes, where $<20 \mathrm{mo}$ is the first class, $>32 \mathrm{mo}$ is the last class, and the other classes are in single months, $\mathrm{M}_{\mathrm{j}}$ = fixed effect of calendar month $j$ of first calving, in 12 classes, $\mathrm{HY}_{\mathrm{k}}=$ fixed effect of herd-year class $k, \mathrm{~s}_{\mathrm{l}}=$ random effect of sire $l$, and $\mathrm{e}_{\mathrm{ijklm}}=$ random error term.

The analysis was conducted with the DMU package, using the AI-REML algorithm (Madsen and Jensen, 2000).

Estimated (co)variance components for CM and LSCS are presented in Table 2 . The estimated heritabilities were 0.03 and 0.11 for CM and LSCS, respectively, which is in agreement with results from univariate analyses of CM (for a shorter period of lactation) (Heringstad et al., 1999), and LSCS (Ødegård et al., 2003b). The estimated genetic correlation between the traits was moderate $(0.53)$, whereas the estimated residual correlation was low (0.10). The results indicate that the 2 traits have some common genetic background, but that they are clearly genetically distinct traits.

In most countries, SCC is recorded monthly rather than bimonthly. More frequent recording implies a higher probability that SCC records will fall within 
Table 1. Summary statistics of data used in bivariate genetic analysis of clinical mastitis (CM) and lactation mean SCS (LSCS).

\begin{tabular}{lc}
\hline Cows with data for CM, no. & $1,334,318$ \\
Cows with data for LSCS, no. & $1,291,707$ \\
Cows with data for CM and LSCS, no. & $1,253,612$ \\
Herd-year classes, CM, no. & 328,194 \\
Herd-year classes, LSCS, no. & 333,273 \\
Mastitis frequency, $\%$ & 20.7 \\
Mean (SD) LSCS & $4.11(1.00)$ \\
Mean (SD) LSCS, for cows with CM = & $4.06(0.97)$ \\
Mean (SD) LSCS, for cows with CM = 1 & $4.26(1.05)$ \\
Average age at first calving, mo & 24.9 \\
\hline
\end{tabular}

${ }^{1}$ Percentage of cows with at least one record of $\mathrm{CM}$ in the period from $15 \mathrm{~d}$ before to $305 \mathrm{~d}$ after first calving.

periods of udder infection. However, the number of records from periods without udder infection will also increase. Hence, more frequent recording is not likely to change the expected value of LSCS, but records would become more precise, with smaller measurement error. Therefore, residual variance is likely to be reduced, increasing residual correlation, but with no effect on size of genetic correlation.

The residual correlation reported in this study $(0.10)$ is well within the range (0.03 to 0.21$)$ of the values obtained in other studies (Emanuelson et al., 1988; Weller et al., 1992; Lund et al., 1994; Pösö and Mäntysaari, 1996; Lund et al., 1999; Kadarmideen and Pryce, 2001). Some of the variation in residual correlation may be explained by different recording intervals and model (e.g., sire vs. animal model, linear vs. threshold model). However, no clear-cut picture can be found for the relationship between size of residual correlation and frequency of SCC recording. The low estimate for the residual correlation and the relatively small difference between mean LSCS for cows with and without mastitis treatments (Table 1) indicate that $\mathrm{CM}$ cases during lactation affect the recorded test-day SCC only to a minor extent. The fact that $\mathrm{CM}$ is recorded on day of treatment, whereas SCC is recorded on a routine bimonthly basis may explain this. Hence, the recorded SCC is probably more affected by unobserved cases of subclinical mastitis rather than observed CM.

In the literature, reports of genetic correlations between CM and SCC have been rather variable (0.30 to 0.97) (Emanuelson et al., 1988; Weller et al., 1992; Lund et al., 1994; Pösö and Mäntysaari, 1996; Lund et al., 1999; Rupp and Boichard, 1999; de Haas et al., 2002a). In this study, the estimated genetic correlation of 0.53 was lower than the most widely accepted value (i.e., the average of 0.7 given by Mrode and Swanson, 1996). However, due to the large amount of data included in this study, our estimate should be highly accurate.

The wide range of genetic correlation estimates may be explained in part by differences in trait definitions and prediction error but may also indicate that the correlation is population-specific. Generally, correlations between continuous and binary traits arise either as a result of a covariance structure between the continuous trait and the underlying liability for the binary trait (relationship strictly on the liability scale), or as a direct relationship between the continuous trait and the classes of the binary trait (relationship strictly on the binary scale), or a combination of both. If the relationship is strictly on the liability scale, the genetic correlation estimated with linear models should, theoretically, equal the correlation between the continuous trait and the underlying liability of the binary trait (Vinson et al., 1976; Gianola, 1982), and thus be independent of the frequency of the binary trait. However, the relationship between LSCS and CM cannot be fully explained by a relationship on the liability scale, as it is well known that mastitis (clinical or subclinical) induces an increase in SCC. Thus, variation in LSCS must, to some extent, be determined by differences in the cows' actual udder health status on the test-days, rather than varying with the underlying liability to mastitis. Therefore, the correlation (genetic and residual) between CM and LSCS will most likely depend on the prevalence of mastitis (clinical and subclinical), and the size of the SCC response to infection. It would be expected that populations with low mastitis frequency would experience a lower genetic correlation between $\mathrm{CM}$ and SCC, as indicated by Kadarmideen and Pryce (2001), who analyzed data from herds grouped according to incidence of CM. Because different mastitiscausing pathogens have specific SCC response patterns (de Haas et al., 2002b), the estimated correlation is expected to vary according to the prevalence of the different pathogens.

Table 2. Estimated parameters from bivariate genetic analysis of clinical mastitis (CM) and lactation mean somatic cell score (LSCS).

\begin{tabular}{llll}
\hline Parameter & CM & LSCS & CM and LSCS \\
\hline Sire (co)variance (SE) & $0.0013(0.0000)$ & $0.0237(0.0009)$ & $0.0029(0.0002)$ \\
Residual (co)variance (SE) & $0.1500(0.0002)$ & $0.8559(0.0012)$ & $0.0372(0.0004)$ \\
Heritability & 0.035 & 0.108 & $\ldots$ \\
Genetic correlation (SE) & $\ldots$ & $\ldots$ & $0.526(0.025)$ \\
Residual correlation (SE) & $\ldots$ & $\ldots$ & $0.104(0.001)$ \\
\hline
\end{tabular}


The variability of the parameter estimates due to the factors described above suggests that more advanced modeling of the relationship between the traits should be encouraged. Gianola et al. (2004) and Ødegård et al. (2003a) have described approaches for analyzing SCC data with mixture models, which may solve some of the problems regarding the relationship between SCC and mastitis. In these models, one can estimate the probability of mastitis by taking into account the effect of unobserved mastitis on observed test-day SCC.

\section{ACKNOWLEDGMENTS}

Access to the data was given by the Norwegian Dairy Herd Recording System (Husdyrkontrollen) in agreement number 6/1998 and 011/2000. GENO Breeding and A. I. Association is acknowledged for providing pedigree information on sires. The project received funding from the Research Council of Norway, TINE Norwegian Dairies BA, and GENO Breeding and A. I. Association.

\section{REFERENCES}

de Haas, Y., H. W. Barkema, and R. F. Veerkamp. 2002a. Genetic parameters of pathogen-specific incidence of clinical mastitis in dairy cows. Anim. Sci. 74:233-242.

de Haas, Y., H. W. Barkema, and R. F. Veerkamp. 2002b. Effect of pathogen-specific clinical mastitis on lactation curves for somatic cell count. J. Dairy Sci. 85:1314-1323.

Emanuelson, U., B. Danell, and J. Philipsson. 1988. Genetic parameters for clinical mastitis, somatic cell count, and milk production estimated by multiple-trait restricted maximum likelihood. J. Dairy Sci. 71:467-476

Gianola, D. 1982. Theory and analysis of threshold characters. J. Anim. Sci. 54:1079-1096.

Gianola, D., J. Ødegård, B. Heringstad, G. Klemetsdal, D. Sorensen, P. Madsen, J. Jensen, and J. Detilleux. 2004. Mixture model for inferring susceptibility to mastitis in dairy cattle: A procedure for likelihood-based inference. Genet. Sel. Evol. 36:3-27.

Heringstad, B., G. Klemetsdal, and J. Ruane. 1999. Clinical mastitis in Norwegian cattle: Frequency, variance components, and genetic correlation with protein yield. J. Dairy Sci. 82:1325-1330.

Kadarmideen, H. N., and J. E. Pryce. 2001. Genetic and economic relationships between somatic cell count and clinical mastitis and their use in selection for mastitis resistance in dairy cattle. Anim. Sci. 73:19-28.

Lund, M. S., J. Jensen, and P. H. Petersen. 1999. Estimation of genetic and phenotypic parameters for clinical mastitis-somatic cell production deviance, and protein yield in dairy cattle using Gibbs sampling. J. Dairy Sci. 82:1045-1051.

Lund, T., F. Miglior, J. C. M. Dekkers, and E. B. Burnside. 1994 Genetic relationship between clinical mastitis, somatic cell count, and udder conformation in Danish Holsteins. Livest. Prod. Sci. 39:243-251.

Madsen, P., and J. Jensen. 2000. A User's Guide to DMU. A Package for Analysing Multivariate Mixed Models. Version 6, release 4 National Institute of Animal Science Research Centre, Foulum, Denmark.

Mrode, R. A., and G. J. T. Swanson. 1996. Genetic and statistical properties of somatic cell count and its suitability as an indirect means of reducing the incidence of mastitis in dairy cattle. Anim. Breed. Abstr. 64:847-857.

Ødegård, J., J. Jensen, P. Madsen, D. Gianola, G. Klemetsdal, and B. Heringstad. 2003a. Detection of mastitis in dairy cattle by use of mixture models for repeated somatic cell scores: A Bayesian approach via Gibbs sampling. J. Dairy Sci. 86:3694-3703.

Ødegård, J., G. Klemetsdal, and B. Heringstad. 2003b. Variance components and genetic trend for somatic cell count in Norwegian cattle. Livest. Prod. Sci. 79:135-144.

Pösö, J., and E. A. Mäntysaari. 1996. Relationships between clinical mastitis, somatic cell score, and production for the first three lactations of Finnish Ayrshire. J. Dairy Sci. 79:1284-1291.

Rupp, R., and D. Boichard. 1999. Genetic parameters for clinical mastitis, somatic cell score, production, udder type traits, and milking ease in first lactation Holsteins. J. Dairy Sci. 82:21982204

Vinson, W. E., J. M. White, and R. H. Kliewer. 1976. Overall classification as a selection criterion for improving categorically scored components of type in Holsteins. J. Dairy Sci. 59:2104-2114.

Weller, J. L., A. Saran, and Y. Zeliger. 1992. Genetic and environmental relationships among somatic cell count, bacterial infection, and clinical mastitis. J. Dairy Sci. 75:2532-2540. 